Historic, Archive Document

Do not assume content reflects current scientific knowledge, policies, or practices. 
1 


\title{
MURRY'S NEW EXTRA EARLY WONDER TOMATO
}

\author{
ORIGINATED BY JOHN MURRY, WHOLESALE MARKET GARDENER \\ STANBERRY, MO.
}

I have often wished that I could write a good description of this tomato, knowing: as I do the many wonderful outstanding superior qualities of this great, new tomato. My only regret is that I am unable to put my thoughts into words. However, even though I could tell you all I know about this wonderful tomato, it would be impossible for you to grasp the full meaning of its real value, because there has never been another tomato like it before. It is the early money variety for market gardeners. This new tomato is an extra early, scarlet fruited variety of superior merit, the vines are exceptionally productive; the fruits are the largest of the extra early sorts, and also most attractive in color; they are nearly round, smooth and of excellent quality. It is the very earliest to ripen and it continues to furnish marketable fruits much longer than other first early varieties; its earliness combined with its wonderful smoothness makes it the finest tomato to be had anywhere; it is an invaluable sort for market gardeners. We consider it the most outstanding extra early, bright red tomato in existence.

A, No. 1, Extra Select Seed, Packet, 50c; 1/2 Ounce, $\$ 1.50 ;$ Ounce, $\$ 2.50$.

\section{Address, JOHN MURRY, TOMATO SPECIALIST}

\author{
STANBERRY, MISSOURI
}


